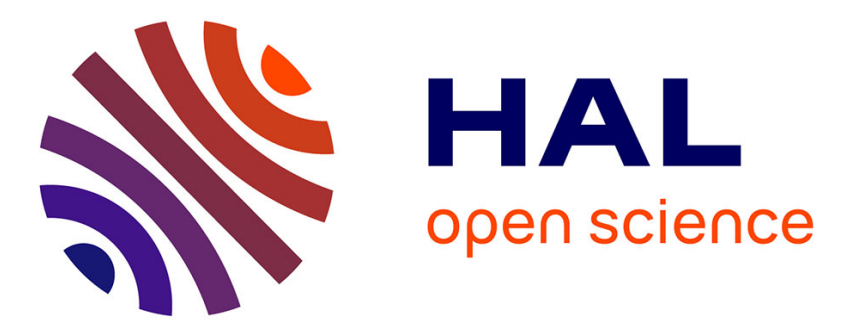

\title{
Short-term browsing by roe deer has little effect on survival and growth of sessile oak seedlings
}

Eric Bideau, M.L. Maublanc, D. Picot, Jean-Pierre Hamard, Philippe Ballon, J.F. Gerard

\section{> To cite this version:}

Eric Bideau, M.L. Maublanc, D. Picot, Jean-Pierre Hamard, Philippe Ballon, et al.. Short-term browsing by roe deer has little effect on survival and growth of sessile oak seedlings. Scandinavian Journal of Forest Research, 2016, 31 (1), pp.40-45. 10.1080/02827581.2015.1054873 . hal-02605469

\section{HAL Id: hal-02605469 \\ https://hal.inrae.fr/hal-02605469}

Submitted on 27 May 2020

HAL is a multi-disciplinary open access archive for the deposit and dissemination of scientific research documents, whether they are published or not. The documents may come from teaching and research institutions in France or abroad, or from public or private research centers.
L'archive ouverte pluridisciplinaire HAL, est destinée au dépôt et à la diffusion de documents scientifiques de niveau recherche, publiés ou non, émanant des établissements d'enseignement et de recherche français ou étrangers, des laboratoires publics ou privés.

$$
\text { Copyright }
$$


Scandinavian Journal of Forest Research, 2016; 31(1): 40-45

DOI: $10.1080 / 02827581.2015 .1054873$

\title{
SHORT COMMUNICATION
}

\section{Short-term browsing by roe deer has little effect on survival and growth of sessile oak seedlings}

\author{
Eric Bideau ${ }^{\mathrm{a}}$, Marie-Line Maublanc ${ }^{\mathrm{a}^{*}}$, Denis Picot $^{\mathrm{a}}$, Jean-Pierre Hamard $^{\mathrm{b}}$, \\ Philippe Ballon ${ }^{\mathrm{b}}$ and Jean-François Gerard ${ }^{\mathrm{a}}$ \\ ${ }^{\mathrm{a}}$ CEFS, INRA, Castanet-Tolosan Cedex, France; ${ }^{\mathrm{b}}$ EFNO, IRSTEA, Nogent-sur-Vernisson, France
}

(Received 27 November 2014; accepted 19 May 2015)

\begin{abstract}
We studied the effect of roe deer (Capreolus capreolus) browsing on the growth and mortality of sessile oak (Quercus petraea) seedlings. First, we measured the height and basal diameter, and counted the number of shoots of the 849 seedlings of an experimental plantation, 60 of which were individually protected by fencing. We then introduced two tame roe deer females every day for three weeks from late May to midJune. Measurements and counts were repeated after roe deer removal, then once again the following winter. We found no significant effect of browsing on mortality, total height, or basal diameter of the seedlings. However, the browsed seedlings exhibited a lower number of shoots despite regrowth observed after roe deer removal. We propose to use the tolerance of oak to deer browsing to promote natural and inexpensive methods, to protect oak during regeneration, such as the spatial arrangement of plants or the use of slash or surrounding vegetation in favourable environments.
\end{abstract}

Keywords: Roe deer; browsing impact; oak seedlings; experimental study

\section{Introduction}

The impact of deer browsing has been highlighted on forest regeneration (Staines \& Welch 1984; Ammer 1996; Motta 1996, 2003; Van Hees et al. 1996; Moore et al. 1999; Palmer et al. 2004; Olesen \& Madsen 2008), on structure, composition, and vegetation dynamics of the forest understory (Horsley et al. 2003; Joys et al. 2004), on other communities living in the forest (Stewart 2001; Allombert et al. 2005; Gill \& Fuller 2007), and more generally on woodland ecology as a whole (Fuller \& Gill 2001; Côté et al. 2004).

The impact on seedlings has been shown to depend on site characteristics, including soil richness or preparation (Olesen \& Madsen 2008; Bergquist et al. 2009), light intensity regime and composition of the ground vegetation (Gill \& Beardall 2001), quantity of surrounding cover (Kay 1993; Moore et al. 1999; Partl et al. 2002), availability and relative quality of alternative food resources (Moser et al. 2006; Miller et al. 2009; Reimoser et al. 2009), and the silvicultural system in place (Reimoser \& Gossow 1996).

As shown by Jensen et al. (2012), ungulates may browse seedlings in all seasons, and Kullberg and Bergström (2001) found in a controlled field-based study that the pedunculate oak

${ }^{*}$ Corresponding author. Email: marie-line.maublanc@toulouse.inra.fr 
(Quercus robur) had the highest degree of winter browsing among eight tree species tested. Nevertheless, Canham et al. (1994) showed that a severe winter clipping on three different tree species had little effect on growth and survival of the seedlings. Similarly, Kullberg and Welander (2003) found that winter browsing had little effect on the growth of pedunculate oak seedlings and caused no mortality during establishment. In contrast, spring browsing may have an effect on seedling growth, as suggested by experimental studies. Braithwaite and Mayhead (1996) showed that survival of sessile oak (Quercus petraea) was high despite high intensities of shoot removal over five years, but growth was significantly depressed in the more severe levels of artificial browsing. Chaar et al. (1997) showed that artificial defoliation of the first growth flush reduced the portion of stem produced by sessile oaks during the growing season. Drexhage and Colin (2003) found that browsed sessile oak seedlings had more branches and greater leaf biomass than unbrowsed seedlings.

Unfortunately, most studies have been performed in multi-ungulate systems (Staines \& Welch 1984; Ammer 1996; Motta 1996, 2003; Van Hees et al. 1996; Kullberg \& Bergström 2001, Joys et al. 2004; Palmer et al. 2004; Focardi \& Tinelli 2005; Jensen et al. 2012), making it difficult to distinguish the impacts of the different species on vegetation structure (Bergquist et al. 2009).

Here, we present an experimental study on the impact of roe deer (Capreolus capreolus) browsing on survival and growth of sessile oak seedlings. The roe deer is currently the most widespread large wild herbivore in Europe. Since the late 1970s, its populations have increased across Europe, mainly due to changes in land use, a lack of predators, and stricter hunting regulations (Gill 1992a). This increase has ecological and sometimes economic consequences associated with damage in forestry (Gill 1992b; Cederlund et al. 1998; Ward et al. 2004). Part of the damage results from antler rubbing by males, but the main impact is due to browsing of seedlings (Cederlund et al. 1998). Moreover, the sessile oak and pedunculate oak are main tree species of the European forests, occurring from Mediterranean to Scandinavian regions, and constitute the basis of Atlantic oak-woods, a habitat of high importance in the European Union's Habitats Directive (Palmer et al. 2004). We used true instead of simulated browsing because oak seedlings are susceptible to manipulation (Ducousseau, pers. comm.) and clipping cannot simulate real browsing perfectly, deer pulling on shoots with their incisors, or grinding them between their molars, according to their resistance (Bideau \& Maublanc 2015).

The aim of the present study was to investigate the response of recently established sessile oak seedlings to roe deer spring browsing. Specifically, we expected (i) browsed seedlings to be unable to entirely replace the lost shoots and (ii) that this would reduce their survival and growth rates albeit slightly.

\section{Methods}

\section{Experiment}

The study was conducted in an experimental site owned by the INRA (National Institute of Agronomic Research) located at Gardouch (43⒉ ${ }^{\prime}$ N $1^{\circ} 40^{\prime}$ E) in southwest France.

In winter 2001 we planted 864 containerized sessile oak seedlings from acorns taken in the Bellême forest (northwest France) and sown and reared in the national forestry nursery of Aixen-Provence (southeast France). The plantation was performed in a $70 \mathrm{~m} \times 70 \mathrm{~m}$ enclosure, and consisted of 24 rows of 36 seedlings each (i.e. a row every $2.5 \mathrm{~m}$, seedlings planted $1.5 \mathrm{~m}$ from each other). A drip watering system was installed to prevent drying out. The underlying 
vegetation, which was regularly mowed, was composed of grasses and forbs, some of which entered the roe deer diet.

At the start of the experiment, that is, from 19 to 23 May $2003\left(\mathrm{~T}_{0}\right)$, we described the 849 surviving seedlings, measuring their height and basal diameter (root collar), and counting their shoots (i.e. the stems of $1 \mathrm{~cm}$ length or more, with one or several leaves). No particular attention was paid to the browsing of leader shoots because mortality of the apical bud, changes in the allocation of shoot elongation between several shoots, and changes in dominance occur frequently in oaks (Harmer 1989, 1992; Collet et al. 1997). We then protected 60 seedlings evenly distributed through the plantation, with individual wire fencing.

Afterwards, two tame roe deer females were introduced into the plantation during the daylight hours for three weeks (26 May-15 June 2003), at the end of which they had browsed most of the 789 unprotected seedlings. An experimenter went with them from time to time to make sure they browsed seedlings throughout the plantation. Water was provided ad libitum. In addition, $600 \mathrm{~g}$ of artificial roe deer pellets (ca. $90 \%$ of the daily needs) was given daily per animal, only in the night pen to encourage the roe deer browsing during the day.

The 60 individual seedling protections were removed at the departure of the roe deer, and from 2 to 6 July $2003\left(\mathrm{~T}_{0}{ }^{\text {') }}\right.$, we again measured the height of the seedlings, and counted the number of shoots they carried. Finally, from 5 to 9 January $2004\left(\mathrm{~T}_{1}\right)$, we checked the status (dead or alive) of each seedling, and when alive, performed the same measurements as those made at $\mathrm{T}_{0}$.

\section{Statistical analysis}

Distributions of height and basal diameter were approximately Gaussian, and their variances did not differ between protected and unprotected seedlings ( $F$-test: $P$-value between 0.09 and 0.69 depending on the variable and the experimental step). Height and basal diameter were therefore left untransformed irrespective of the analysis. In contrast, shoot number needed to be square-root transformed for its distribution to become more symmetrical, and its variance more homogeneous between samples ( $F$-test: $P$-value between 0.27 and 0.96 after transformation). Accordingly, shoot number was square-root transformed for all statistical inferences with the exception of correlations.

Height, basal diameter, and (square-root transformed) number of shoots of protected and unprotected seedlings were compared, using the two-sample $t$-test. Within-sample difference in square-root transformed number of shoots between $\mathrm{T}_{1}$ and $\mathrm{T}_{0}$ ' was tested, using the pairedsample $t$-test. In order to test whether the between-samples difference in shoot number varied between $\mathrm{T}_{0}$, and $\mathrm{T}_{1}$, we used a linear mixed-effect model with the square-root transformed number of shoots as dependent variable, time $\left(\mathrm{T}_{0}, \mathrm{vs} . \mathrm{T}_{1}\right.$ ) and treatment (protected vs. unprotected) as fixed-effect factors, and seedling identity as random-effect factor. Once the model was fitted by maximizing restricted log-likelihood (REML method), we tested for the time*treatment interaction using the $F$-test.

Pearson's correlations between numbers of shoots at $\mathrm{T}_{1}$ and $\mathrm{T}_{0}$, , and $\mathrm{T}_{1}$ and $\mathrm{T}_{0}$ were compared, using Williams' $t$-test (Williams 1959). Fisher's exact test was used for comparing the proportions of protected and unprotected seedlings that survived (/died) between $\mathrm{T}_{0}$, and $\mathrm{T}_{1}$. The effect of shoot number on mortality was analysed, using logistic regression (generalized linear model; dependent variable distribution: binomial; link function: logit) and associated test on deviance. 
Table 1. Mean height, basal diameter, and shoot number $( \pm S E)$ of the protected and unprotected oak seedlings at times $\mathrm{T}_{0}, \mathrm{~T}_{0}$, and $\mathrm{T}_{1}$. Between brackets: mean shoot number $( \pm S E)$ of the unprotected seedlings alive at $\mathrm{T}_{1}$.

\begin{tabular}{|c|c|c|c|c|c|c|}
\hline & \multicolumn{2}{|c|}{$\mathrm{T}_{0}$} & \multicolumn{2}{|c|}{$\mathrm{T}_{0}{ }^{\prime}$} & \multicolumn{2}{|c|}{$\mathrm{T}_{1}$} \\
\hline & Unprotected & Protected & Unprotected & Protected & Unprotected & Protected \\
\hline Height (cm) & $48.87 \pm 0.29$ & $47.75 \pm 1.10$ & $46.14 \pm 0.31$ & $46.78 \pm 1.21$ & $45.90 \pm 0.36$ & $45.86 \pm 1.32$ \\
\hline Collar diameter $(\mathrm{cm})$ & $0.91 \pm 0.01$ & $0.88 \pm 0.02$ & - & - & $1.01 \pm 0.01$ & $1.00 \pm 0.03$ \\
\hline Shoot number & $21.43 \pm 0.32$ & $20.70 \pm 1.12$ & $\begin{array}{c}12.46 \pm 0.27 \\
(12.70 \pm 0.27)\end{array}$ & $23.38 \pm 1.36$ & $18.13 \pm 0.35$ & $21.73 \pm 1.37$ \\
\hline
\end{tabular}

All the statistical analyses were performed using R software (R Core Team 2014), and more specifically the nlme package (Pinheiro et al. 2013) for the linear mixed-effect model, and the cocor package (Diedenhofen 2013) for the comparison of correlation coefficients. In the Results section, tests are two-sided unless otherwise specified.

\section{Results}

\section{Immediate roe deer impact at $T_{0}$,}

Before roe deer introduction $\left(\mathrm{T}_{0}\right)$, the protected $(n=60)$ and unprotected $(n=789)$ seedlings did not differ in morphology (Table 1; height: $t_{847}=1.015, P=0.31$; basal diameter: $t_{847}=1.092$, $P=0.28$; number of shoots: $\left.t_{847}=0.638, P=0.52\right)$. After roe deer removal $\left(\mathrm{T}_{0}{ }^{\prime}\right)$, they remained similar in height (Table 1; one-sided $t$-test: $t_{847}=-0.551, P=0.29$ ), but unprotected seedlings exhibited a much lower number of shoots than protected seedlings (Table 1; one-sided $t$-test: $\left.t_{847}=-9.110, P<0.001\right)$.

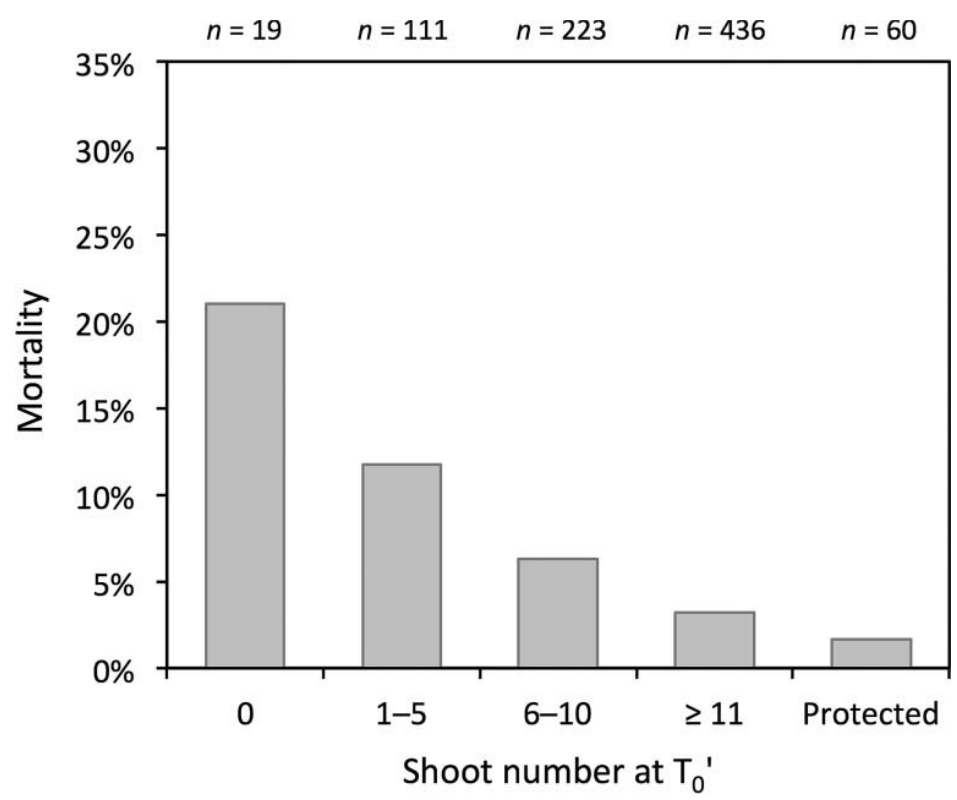

Figure 1. Mortality rate between $\mathrm{T}_{0}$, and $\mathrm{T}_{1}$ as a function of the number of shoots carried by the unprotected seedlings at $\mathrm{T}_{0}$ '. The only protected oak seedling that died carried 29 shoots at $\mathrm{T}_{0}$ '. $n$ : sample size. 


\section{Seedling survival at $T_{1}$}

Survival was high between $\mathrm{T}_{0}{ }^{\prime}$ and $\mathrm{T}_{1}$, and did not significantly differ between protected and unprotected seedlings (protected: 98.3\%, $n=60$; unprotected: 94.3\%, $n=789$; one-sided Fisher's exact test: $P=0.15$ ). However, further analysis shows that mortality in unprotected seedlings increased as the number of their shoots at $\mathrm{T}_{0}{ }^{\prime}$ decreased (deviance: $\chi_{1}^{2}=16.337 ; P<0.001$ ), and became significantly higher than that of protected seedlings when less than 11 shoots remained after browsing (Figure 1; one-sided Fisher's exact test: $P=0.037$ ).

\section{Seedling growth at $T_{1}$}

Protected $(n=59)$ and unprotected seedlings $(n=744)$ that were alive at $\mathrm{T}_{1}$ exhibited similar heights (Table 1; one-sided $t$-test: $t_{801}=0.028, P=0.51$ ) and basal diameters (one-sided $t$-test: $t_{801}=0.314, P=0.62$ ) but different numbers of shoots (one-sided $t$-test: $t_{801}=-2.787, P=0.003$ ). The number of shoots of unprotected seedlings at $\mathrm{T}_{1}$ showed greater correlation to the number of shoots at $\mathrm{T}_{0}$ ' (Figure 2a; $\left.r=0.637, P<0.001\right)$ than to the number of shoots at $\mathrm{T}_{0}(r=0.556$, $P<0.001$; comparison between the two correlation coefficients: $t_{741}=2.927, P=0.004$ ), illustrating a durable effect of browsing on seedling growth. However, the difference in shoot number between protected and unprotected seedlings was lower at $\mathrm{T}_{1}$ than between the same seedlings at $\mathrm{T}_{0}$ ' (Table 1: $F_{1,801}=47.556, P<0.001$ ). Indeed, whereas shoot number decreased slightly between $\mathrm{T}_{0}$ ' and $\mathrm{T}_{1}$ in protected seedlings (paired-sample $t$-test: $t_{58}=-2.631, P=0.011$ ), it increased on average in the surviving unprotected seedlings (paired-sample $t$-test: $t_{743}=19.687$, $P<0.001)$. Increase in shoot number was greater when seedlings had lost a larger number of shoots in the presence of roe deer (Figure 2b; Pearson's correlation: $r=0.405, P<0.001$ ).
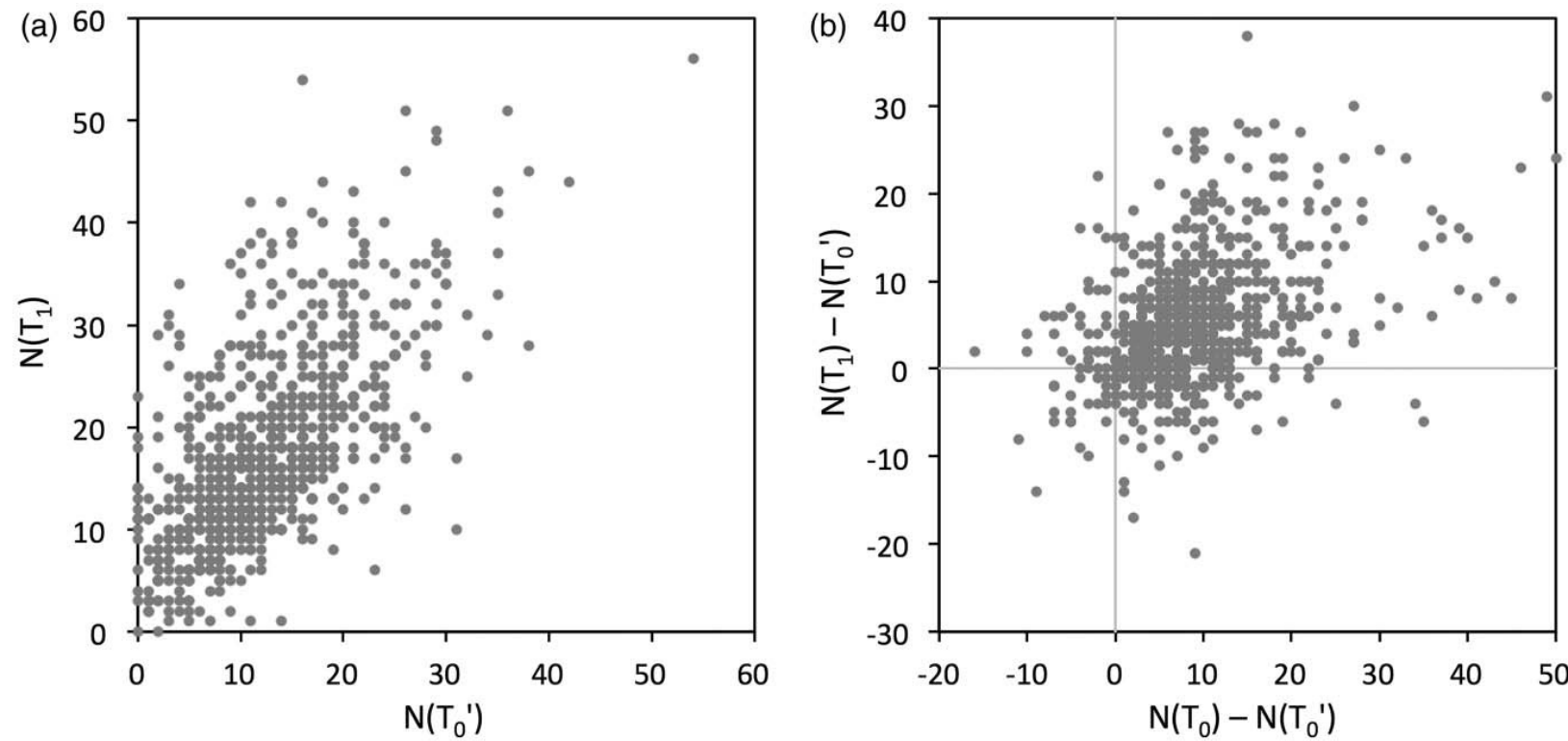

Figure 2. (a) Shoot number at $\mathrm{T}_{1}$ as a function of shoot number at $\mathrm{T}_{0}$ ' among the unprotected oak seedlings that remained alive. (b) Difference in shoot number between $\mathrm{T}_{1}$ and $\mathrm{T}_{0}$ ' as a function of the difference in shoot number between $\mathrm{T}_{0}$ and $\mathrm{T}_{0}$ ' for the same seedlings. 


\section{Discussion}

Just before the growing season following the experimental roe deer browsing period, the mortality of unprotected plants was low, and not significantly different from that of protected plants. This result is even more striking when considering the challenging conditions of the severe drought-heat wave of 2003, which led to a lack of growth of all seedlings between $\mathrm{T}_{0}$, and $\mathrm{T}_{1}$ despite the drip watering system installed. This high survival rate is in agreement with the results obtained from simulated browsing on pedunculate or sessile oak: the effect of clipping on oak survival remained non-significant after up to five years of treatment (Braithwaite \& Mayhead 1996; Harmer 2001). In the same way, little effect of browsing or clipping was found on mortality in European beech (Fagus sylvatica, Harmer 2001), Norway spruce (Picea abies, Bergquist et al. 2003), and Scots pine (Pinus sylvestris, Bergquist et al. 2009). Other tree species may suffer more impact from browsing, as shown by the significant decrease in survival of sycamore maple (Acer pseudoplatanus), European ash (Fraxinus excelsior), or silver birch (Betula pendula), after natural or simulated browsing (Harmer 2001; Bergquist et al. 2009).

In the present study, the main impact of deer browsing on oak seedlings was a decrease in the number of shoots. This was significant immediately after the removal of deer and persisted until the following growing season. We did not estimate leaf biomass, but Drexhage and Colin (2003) showed that the leaf contribution to the total biomass was the same for 6-7-year-old browsed (unfenced) and unbrowsed (fenced) sessile oak seedlings, while more biomass was allocated to the stem in unbrowsed plants and to the roots in browsed plants. Van Hees et al. (1996) showed that differences in leaf area between browsed (unfenced) and unbrowsed (fenced) pedunculate oak saplings with the same shoot biomass were not significant, 5-6 years after fencing.

Nevertheless, the regeneration success of oaks in natural conditions may be compromised or at least delayed by a combination of factors including light level, inter-specific competition, and deer browsing (Van Hees et al. 1996; Götmark et al. 2005; Harmer \& Morgan 2007; Bergquist et al. 2009). The decrease in the number of shoots may actually lead to delayed growth as reported by most authors in various species (Welch et al. 1992; Van Hees et al. 1996; Harmer 2001; Bergquist et al. 2003, 2009; Vila et al. 2003). Though mortality rate did not differ significantly in our experiment between protected and unprotected seedlings, it became significantly higher in the unprotected plants when less than 11 shoots remained. This trend could become substantial after a few years of browsing. Only long-term studies can establish whether oaks can withstand browsing and competition in forests and recruit into the tall canopies of semi-natural forests. Oaks are known to survive repeated partial removal of the above-stump parts by resprouting (Braithwaite \& Mayhead 1996; Harmer 2001) and Götmark and Kiffer (2014) showed that oaks can regenerate in the long term among competing tree species (especially shade-tolerant trees) and under browsing pressure from herbivores.

This tolerance of oak to browsing in favourable environments should allow the use of natural methods of protection, such as the spatial arrangement of preferred plants in relation to less preferred ones (Moore et al.1999; Bergman et al. 2005) or the use of slash or surrounding vegetation as physical protection or attractive alternative food (Hay 1986; Buckley et al. 1998; Milleret al. 2006; de Chantal \& Granström 2007; Gómez-Aparicio et al. 2004; Götmark et al. 2011; Jensen et al. 2012). As suggested by Ward et al. (2008), these efforts to protect oak regeneration should be combined with deer population management based on reliable indexbased methods (Morellet et al. 2007), allowing deer densities to be matched with habitat capacities. 


\section{Acknowledgements}

We thank Peter Winterton for editing the language of the manuscript.

\section{Disclosure statement}

No potential conflict of interest was reported by the authors.

\section{Funding}

The construction of the experimental station was jointly financed by the National Institute of Agronomic Research (INRA) and the Midi-Pyrénées Region.

\section{References}

Allombert S, Stockton S, Martin J-L. 2005. A natural experiment on the impact of overabundant deer on forest invertebrates. Conserv Biol. 19:1917-1929.

Ammer C. 1996. Impact of ungulates on structure and dynamics of natural regeneration of mixed mountain forests in the Bavarian Alps. For Ecol Manage. 88:43-53.

Bergman M, Iason GR, Hester AJ. 2005. Feeding patterns by roe deer and rabbits on pine, willow and birch in relation to spatial arrangement. Oikos. 109:513-520.

Bergquist J, Bergström R, Zakharenka A. 2003. Responses of young Norway spruce (Picea abies) to winter browsing by roe deer (Capreolus capreolus): effects on height growth and stem morphology. Scand J For Res. 18:368-376.

Bergquist J, Löf M, Örlander G. 2009. Effects of roe deer browsing and site preparation on performance of planted broadleaved and conifer seedlings when using temporary fences. Scand J For Res. 24:308-317.

Bideau E, Maublanc ML. 2015. Histoire de chevreuils: comment mange un chevreuil. [cited 2015 July 31]. Available from: https://chevreuils.wordpress.com/2015/04/22/comment-mange-un-chevreuil-2/

Braithwaite TW, Mayhead GJ. 1996. The effects of simulated browsing on the growth of sessile oak (Quercus petraea (Matt.) Lieblein). Arboricultural J. 20:59-64.

Buckley DS, Sharik TL, Isebrands JG. 1998. Regeneration of northern red oak: positive and negative effects of competitor removal. Ecology. 79:65-78.

Canham CD, McAninch JB, Wood DM. 1994. Effects of the frequency, timing, and intensity of simulated browsing on growth and mortality of tree seedlings. Can J For Res. 24:817-825.

Cederlund G, Bergquist J, Kjellander P, Gill R, Gaillard J-M, Boisaubert B, Ballon P, Duncan P. 1998. Managing roe deer and their impact on the environment: maximising the net benefits to society. In: Andersen R, Duncan P, Linnell JDC, editors. The European roe deer: the biology of success. Oslo: Scandinavian University Press; p. 337-372.

Chaar H, Colin F, Leborgne G. 1997. Artificial defoliation, decapitation of the terminal bud, and removal of the apical tip of the shoot in sessile oak seedlings and consequences on subsequent growth. Can J For Res. 27:16141621.

de Chantal M, Granström A. 2007. Aggregations of dead wood after wildfire act as browsing refugia for seedlings of Populus tremula and Salix caprea. For Ecol Manage. 250:3-8.

Collet C, Colin F, Bernier F. 1997. Height growth, shoot elongation and branch development of young Quercus petraea grown under different levels of resource availability. In Ann Sci Forest. 54:65-81.

Côté SD, Rooney TP, Tremblay J-P, Dussault C, Waller DM. 2004. Ecological impacts of deer overabundance. Annu Rev Ecol Evol Syst. 35:113-147.

Diedenhofen B. 2013. cocor: comparing correlations (version 1.0-0). [cited 2015 May 2]. Available from: http://r.birkdiedenhofen.de/pckg/cocor/

Drexhage M, Colin F. 2003. Effects of browsing on shoots and roots of naturally regenerated sessile oak seedlings. Ann For Sci. 60:173-178. 
Focardi S, Tinelli A. 2005. Herbivory in a Mediterranean forest: browsing impact and plant compensation. Acta Oecol. 28:239-247.

Fuller RJ, Gill RMA. 2001. Ecological impacts of increasing numbers of deer in British woodland. Forestry. 74:193199.

Gill RMA. 1992a. A review of damage by mammals in north temperate forests: 1. Deer. Forestry. 65:145-169.

Gill RMA. 1992b. A review of damage by mammals in north temperate forests: 3. Impact on trees and forests. Forestry. 65:363-388.

Gill RMA, Beardall V. 2001. The impact of deer on woodlands: the effects of browsing and seed dispersal on vegetation structure and composition. Forestry. 74:209-218.

Gill RMA, Fuller RJ. 2007. The effects of deer browsing on woodland structure and songbirds in lowland Britain. Ibis. 149:119-127.

Gómez-Aparicio L, Zamora R, Gómez JM, Hódar JA, Castro J, Baraza E. 2004. Applying plant facilitation to forest restoration: a meta-analysis of the use of shrubs as nurse plants. Ecol Appl. 14:1128-1138.

Götmark F, Fridman J, Kempe G, Norden B. 2005. Broadleaved tree species in conifer-dominated forestry: regeneration and limitation of saplings in southern Sweden. For Ecol Manage. 214:142-157.

Götmark F, Kiffer C. 2014. Regeneration of oaks (Quercus robur/Q. petraea) and three other tree species during long-term succession after catastrophic disturbance (wind-throw). Plant Ecol. 215:1067-1080.

Götmark F, Schott KM, Monrad JA. 2011. Factors influencing presence-absence of oak (Quercus spp.) seedlings after conservation-oriented partial cutting of high forests in Sweden. Scand J For Res. 26:136-145.

Harmer R. 1989. The effect of mineral nutrients on growth, flushing, apical dominance and branching in Quercus petraea (Matt.) Liebl. Forestry. 62:383-396.

Harmer R. 1992. Relationships between shoot length, bud number and branch production in Quercus petraea (Matt.) Liebl. Forestry. 65:61-72.

Harmer R. 2001. The effect of plant competition and simulated summer browsing by deer on tree regeneration. $\mathbf{J}$ Appl Ecol. 38:1094-1103.

Harmer R, Morgan G. 2007. Development of Quercus robur advance regeneration following canopy reduction in an oak woodland. Forestry. 80:137-149.

Hay ME. 1986. Associational plant defences and the maintenance of species diversity: turning competitors into accomplices. Am Nat. 128:617-641.

Horsley SB, Stout SL, de Calesta DS. 2003. White-tailed deer impact on the vegetation dynamics of a Northern hardwood forest. Ecol Appl. 13:98-118.

Jensen AM, Götmark F, Löf M. 2012. Shrubs protect oak seedlings against ungulate browsing in temperate broadleaved forests of conservation interest: a field experiment. For Ecol Manage. 266:187-193.

Joys AC, Fuller RJ, Dolman PM. 2004. Influences of deer browsing, coppice history, and standard trees on the growth and development of vegetation structure in coppiced woods in lowland England. For Ecol Manage. 202:23-37.

Kay S. 1993. Factors affecting severity of deer browsing damage within coppiced woodlands in the south of England. Biol Conserv. 63:217-222.

Kullberg Y, Bergström R. 2001. Winter browsing by large herbivores on planted deciduous seedlings in southern Sweden. Scand J For Res. 16:371-378.

Kullberg Y, Welander NT. 2003. Effects of simulated winter browsing and drought on growth of Quercus robur L. seedlings during establishment. For Ecol Manage. 173:125-133.

Miller AM, McArthur C, Smethurst PJ. 2006. Characteristics of tree seedlings and neighbouring vegetation have an additive influence on browsing by generalist herbivores. For Ecol Manage. 228:197-205.

Miller BF, Campbell TA, Laseter BR, Ford WM, Miller KV. 2009. White-tailed deer herbivory and timber harvesting rates: implications for regeneration success. For Ecol Manage. 258:1067-1072.

Moore NP, Hart JD, Langton SD. 1999. Factors influencing browsing by fallow deer Dama dama in young broadleaved plantations. Biol Conserv. 87:255-260.

Morellet N, Gaillard J-M, Hewison AJM, Ballon P, Boscardin Y, Duncan P, Klein F, Maillard D. 2007. Indicators of ecological change: new tools for managing populations of large herbivores. J Appl Ecol. 44:634-643.

Moser B, Schütz M, Hindenlang KE. 2006. Importance of alternative food resources for browsing by roe deer on deciduous trees: the role of food availability and species quality. For Ecol Manage. 226:248-255.

Motta R. 1996. Impact of wild ungulates on forest regeneration and tree composition of mountain forests in the Western Italian Alps. For Ecol Manage. 88:93-98.

Motta R. 2003. Ungulate impact on rowan (Sorbus aucuparia L.) and Norway spruce (Picea abies (L.) Karst.) height structure in mountain forests in the Eastern Italian Alps. For Ecol Manage. 181:139-150. 
Olesen CR, Madsen P. 2008. The impact of roe deer (Capreolus capreolus), seedbed, light and seed fall on natural beech (Fagus sylvatica) regeneration. For Ecol Manage. 255:3962-3972.

Palmer SCF, Mitchell RJ, Truscott AM, Welch D. 2004. Regeneration failure in Atlantic oakwoods: the roles of ungulate grazing and invertebrates. For Ecol Manage. 192:251-265.

Partl E, Szinovatz V, Reimoser F, Schweiger-Adler J. 2002. Forest restoration and browsing impact by roe deer. For Ecol Manage. 159:87-100.

Pinheiro J, Bates D, DebRoy S, Sarkar D and the R Development Core Team. 2013. nlme: linear and nonlinear mixed effects models. R package version 3.1-113.

R Core Team. 2014. R: A language and environment for statistical computing. Vienna: R Foundation for Statistical Computing. [cited 2015 May 2]. Available from: http://www.R-project.org/

Reimoser S, Gossow H. 1996. Impact of ungulates on forest vegetation and its dependence on the silvicultural system. For Ecol Manage. 88:107-119.

Reimoser S, Partl E, Reimoser F, Vospernik S. 2009. Roe-deer habitat suitability and predisposition of forest to browsing damage in its dependence on forest growth-model sensitivity in an alpine forest region. Ecol Model. 220:2231- 2243 .

Staines BW, Welch D. 1984. Habitat selection and impact of red (Cervus elaphus L.) and roe (Capreolus capreolus L.) deer in a Sitka spruce plantation. Proc R Soc Edinb Nat Environ B. 82:303-319.

Stewart AJA. 2001. The impact of deer on lowland woodland invertebrates: a review of the evidence and priorities for future research. Forestry. 74:259-270.

Van Hees AFM, Kuiter AT, Slim PA. 1996. Growth and development of silver birch, pedunculate oak and beech as affected by deer browsing. For Ecol Manage. 88:55-63.

Vila B, Torre F, Guibal F, Martin JL. 2003. Growth change of young Picea sitchensis in response to deer browsing. For Ecol Manage. 180:413-424.

Ward AI, White PCL, Smith A, Critchley CH. 2004. Modelling the cost of roe deer browsing damage to forestry. For Ecol Manage. 191:301-310.

Ward AI, White PCL, Walker NJ, Critchley CH. 2008. Conifer leader browsing by roe deer in English upland forests: effects of deer density and understorey vegetation. For Ecol Manage. 256:1333-1338.

Welch D, Staines BW, Scott D French DD. 1992. Leader browsing by red and roe deer on young Sitka spruce trees in western Scotland II. Effects on growth and tree form. Forestry. 65:309-330.

Williams EJ. 1959. The comparison of regression variables. J Roy Stat Soc B. 21:396-399. 